\title{
Identification of volatile compounds in thinning discards from plum trees (Prunus salicina Lindl.) cultivar Harry Pickstone
}

\author{
Identificação de compostos voláteis de frutos de raleio de \\ ameixeira (Prunus salicina Lindl.) cultivar Harry Pickstone
}

\begin{abstract}
Rossana PODESTÁ ${ }^{1}$, Cristiane Manfé PAGLIOSA ${ }^{2}$, Manoela Alano VIEIRA², João Gustavo PROVESI ${ }^{2}$, Edna Regina AMANTE ${ }^{2 *}$, Ana Lúcia Bertarello ZENI ${ }^{3}$, Ismael RAITZ ${ }^{4}$, Ricardo Andrade REBELO ${ }^{4}$
\end{abstract}

\begin{abstract}
Plum (Prunus salicina Lindl. cv. Harry Pickstone), a China indigenous fruit, is widely produced and consumed in countries such as Japan and Brazil. The practice of thinning is common in horticulture and the fruits removed are discarded as waste. Like the great majority of vegetables, these thinning discards also contain essential oils which have not been investigated until the present time. The extraction of the plum thinning discards volatile oil, through the hydrodistillation method, produced a yield of $0.06 \%$ ( $\mathrm{m} / \mathrm{m})$ and a total of 21 components were identified, with 11 of them being responsible for $72,9 \%$ of the total oil composition. The major compounds determined through GC and GC-MS were Z-a-bisabolene (13.7\%), n-hexadecanoic acid (12.7\%), phytol (12.7\%), and $\beta$-caryophyllene (10.4\%).

Keywords: plum; thinning; essential oils.
\end{abstract}

\section{Resumo}

A ameixa (Prunus salicina Lindl. cv. Harry Pickstone), originária da China, é amplamente produzida e consumida em países como o Japão e o Brasil. A prática do raleio é comum na fruticultura e as frutas que são removidas são descartadas como resíduo. Como a grande maioria dos vegetais, estes frutos de raleio também contêm óleos essenciais; porém, eles não foram investigados. A extração do óleo volátil de ameixa de raleio, pelo método de hidrodestilação, obteve rendimento de $0,06 \%(\mathrm{~m} / \mathrm{m})$ e um total de 21 componentes foram identificados, dos quais 11 são responsáveis por $72,9 \%$ da composição total do óleo. Os principais componentes determinados por CG-DIC e CG-EM foram Z- $\alpha$ bisaboleno (13,7\%), ácido n-hexadecanoico (12,7\%), fitol (12,7\%) e $\beta$-cariofileno (10,4\%).

Palavras-chave: ameixa; raleio; óleos essenciais.

\section{Introduction}

The plum tree Prunus salicina Lindl., China indigenous, was developed in Japan for alimentary purposes. It is considered one of the most productive plum species for the climatic conditions in the south of Brazil (STEINBERG, 1990). As in the other species in the Prunus genus, manual thinning of plum trees is performed annually to assure better growth of their fruits. This process eliminates part of the fruits, sometimes even the flowers, and it seeks to improve the quality of the remaining fruits, increase their size, prevent branches from breaking, alternate pests and diseases production control, and to preserve the levels of nutrients. It also provides better formation and growth of shoots for production in the following year (FAUST, 1989). Most fruit growers remove 80 to $90 \%$ of the plants fruits. According to Augustí et al. (1999) in studies with peach trees, the best effects of thinning are achieved when 60 to $80 \%$ of the fruits are eliminated. Such procedure is very costly and it generates thinning discards, which have had no commercial value so far (GONZÁLEZ-ROSSIA et al., 2006). Essential oils, also referred to as volatile oils, are mixtures of several compounds, such as terpene hydrocarbons, alcohols, aldehydes, ketones, phenols, esters, lactones, among others (SIMÕES; SPITZER, 2004). The interest in volatile compounds is increasing because they greatly influence the flavour and aroma of foods (FLAMINI; TEBANO; CIONI, 2008). Even when in small concentrations in vegetables, they have multiple applications which justify such great interest in different fields, such as the chemical, pharmaceutical, and food industries (WANNES; MHAMDI; MARZOUK, 2009). Like the great majority of vegetables, the thinning discards also contain essential oils; however, they have not been investigated until the present moment. Thus, this study is the first to propose investigation of the composition of essential oils in the thinning discards from plum trees (Prunus salicina Lindl.).

\footnotetext{
Received 7/11/2009

Accepted 5/6/2010 (004509)

Department of Food Engineering, Federal University of Santa Catarina, Campus Universitário, Trindade, CEP 88040-900, Florianópolis, SC, Brazil

2 Department of Food Science and Technology, Federal University of Santa Catarina, Rod. Admar Gonzaga, 1346, Itacorubi, CEP 88034-001, Florianópolis, SC, Brazil, e-mail:eamante@cca.ufsc.br

${ }^{3}$ Department of Natural Sciences, Regional University of Blumenau, Campus I, Rua Antônio da Veiga, 140, Victor Konder, CEP 89012-900, Blumenau, SC, Brazil

4 Department of Chemistry, Regional University of Blumenau, Campus I, Rua Antônio da Veiga, 140, Victor Konder, CEP 89012-900, Blumenau, SC, Brazil

${ }^{*}$ Corresponding author
} 


\section{Materials and methods}

\subsection{Plant material}

After 45 days of floration, thinning discards from the plum tree Prunus salicina Lindl. cv. Harry Pickstone (crop of 2007) were collected manually and randomly in four orchards in Frei Rogério, State of Santa Catarina, Brazil, following the thinning procedures adopted by local fruit growers. The samples collected from the four orchards were mixed (pool), frozen in a freezer (Frigostrela, model PF-5) at $-40^{\circ} \mathrm{C}$, packaged in airtight plastic bags and aluminium packed, they were then stored at $-20^{\circ} \mathrm{C}$ and submitted to hydrodistilation and analysis in GC-MS.

\subsection{Extraction of essential oil}

The samples (500 $\mathrm{g}$ of vegetable material) were placed in a $600 \mathrm{~mL}$ round bottom flask with $2,000 \mathrm{~mL}$ of distilled water and adapted to a modified Clevenger-type apparatus (GOTTLIEB; MAGALHÃES, 1960). The hydrodistillation was carried out for 3 hours under nitrogen atmosphere. The steam distillates were extracted 3 times with $10 \mathrm{~mL}$ of bi-distilled dichloromethane. A small fraction of water in the combined organic phase was removed by the addition of a small amount of anhydrous magnesium sulphate, which was removed by filtration. The volatiles were then concentrated by evaporating dichloromethane with nitrogen gas. The yields were calculated based on the dry weight of the plant materials (JANTAN et al., 2005; REHMAN et al., 2008).

\subsection{Identification of volatile compounds}

The GC-FID (Gas Chromatography - Flame Ionization Detector) was performed using a Shimadzu 14-B gas chromatograph with a capillary column (Simplicity-1/Supelco, $30 \mathrm{~m} \times 0.25 \mathrm{~mm}$ i.d. $\times 0.25 \mu \mathrm{m}$ film thickness). The following analytical conditions were employed: sample injection $(0.5 \mu \mathrm{L})$; carrier gas helium at $100 \mathrm{kPa}$ constant pressure, flow rate $1 \mathrm{~mL} /$ minute; split mode; injector temperature $220{ }^{\circ} \mathrm{C}$; and FID $240{ }^{\circ} \mathrm{C}$. The oven temperature was programmed from $60{ }^{\circ} \mathrm{C}$ ( 0 minute) to $195{ }^{\circ} \mathrm{C}$ at $3{ }^{\circ} \mathrm{C}$ minute gradient, it was then increased at a rate of $20^{\circ} \mathrm{C}$ minute from 195 to $235^{\circ} \mathrm{C}$, which was held for 30 minutes. The components quantification was based on their GC peak areas, with no correction for response factors. The qualitative analysis was conducted in a Varian CP-3800 gas chromatograph equipped with a Saturn 2000 mass selective detector set at $70 \mathrm{eV}$ and with a capillary column (CP-Sil $8 \mathrm{CB}, 30 \mathrm{~m} \times 0.25 \mathrm{~mm}$ i.d. $\times 0.25 \mu \mathrm{m}$ film thickness). The operation conditions were the same as previously described. The components identification was made through computer library search based on the matching of MS spectra (NIST 2002), comparison with literature data (ADAMS, 2007) and experimental arithmetic indices (AI) calculated according to Dool and Kratz equation (1963), with reference to an homologous series of $\mathrm{n}$-alkanes $\left(\mathrm{C}_{10}-\mathrm{C}_{25}\right)$ analyzed under the same GC-FID conditions described above.

\section{Results and discussion}

Through hydrodistillation, the average yield of the essential oil in dry weight basis was $0.06 \%(\mathrm{~m} / \mathrm{m})$. Twenty one compounds were identified in the essential oil of thinning discards from Prunus salicina Lindl. cv. Harry Pickstone; 11 of these compounds made up approximately $72.9 \%$ of the essential oil - shown in Table 1, with their respective arithmetic indices (AI). Satisfactory correlation was observed for the calculated AI and the literature values (ADAMS, 2007), providing an efficient tool to discriminate between isomeric sesquiterpenes with similar mass spectra. The major compounds found were Z-a-bisabolene (13.7\%), phytol (12.7\%), n-hexadecanoic acid (12.7\%), and $\beta$-caryophyllene (10.4\%). Utsunomiya et al. (2005), analysed barks of the Japanese apricot tree Prunus mume and also reported Z-a-bisabolene (7.49\%) among its major compounds.

The presence of a compound corresponding to $3.6 \%$ of the sample, with a mass spectrum presenting a mass/charge ratio of 149 (base peak, $\mathrm{C}_{8} \mathrm{H}_{5} \mathrm{O}_{3}$ ), can be related to a phthalate derivative (SILVERSTEIN; WEBSTER; KIEMLE, 2007). Alkyl phthalates are common plasticizers for polyvinyl chloride and are also employed as addictive in oil machinery (DI BELLA et al., 2004); therefore, they are both considered sources of contamination.

In a certain species, the concentration of each one of the compounds of its volatile oil can vary during the development of the vegetable (SIMÕES; SPITZER, 2004). This fact hinders

Table 1. Main compounds of the essential oil of plums from thinning discards of Prunus salicina Lindl. cv. Harry Pickstone.

\begin{tabular}{|c|c|c|c|c|}
\hline Number & Compound & $\mathrm{AI}_{\mathrm{Calc}}$ & $\mathrm{AI}_{\text {Lit }}$ & $\%$ \\
\hline 1 & $\gamma$-Terpineol & 1197 & 1199 & 2.8 \\
\hline 2 & a-Copaene & 1373 & 1374 & 2.1 \\
\hline 3 & $\beta$-Caryophyllene & 1417 & 1417 & 10.4 \\
\hline 4 & E-a-Bergamotene & 1432 & 1432 & 3.8 \\
\hline 5 & a-Caryophyllene & 1454 & 1452 & 2.4 \\
\hline 6 & Z- $\beta$-Guaiene & 1487 & 1492 & 2.6 \\
\hline 7 & Viridiflorene & 1494 & 1496 & 2.3 \\
\hline 8 & Z-a-Bisabolene & 1507 & 1506 & 13.7 \\
\hline 9 & $\delta$-Cadinene & 1517 & 1522 & 7.4 \\
\hline 10 & n-Hexadecanoic acid & 1969 & 1959 & 12.7 \\
\hline 11 & Phytol $^{\mathrm{a}}$ & - & - & 12.7 \\
\hline
\end{tabular}

${ }^{a}$ Characterization based on GC-MS only. 
a comparison between the thinning discards and the ripe fruits of plums of the same species. Besides, there are few studies involving the investigation of volatile compounds of Prunus salicina Lindl. Lozano et al. (2008) stated that cultivars of Japanese plums showed a relatively small number of volatile compounds when compared to other members of the Prunus genus, such as peach and nectarine. Other works found several compounds with six carbons (C6) in ripe plums, such as hexanol, hexanal, and their esters, which are important in the aroma of the fruit (HORVAT et al., 1992; GOMEZ; LEDBETTER; HARTSELL, 1993; LOZANO et al., 2008). The presence of C6 compounds may happen because of the activity of the lipoxygenase enzyme on the linoleic and linolenic acids, which make up the lipid membrane (HATANAKA, 1993). These compounds were found in small amount in the essential oil of thinning discards from plum trees. Such fact is probably related to the fruit maturation stage, because the process of flavour and aroma formation is dynamic and it increases during the more advanced stages of maturation through a series of biochemical processes that lead to the generation of volatile compounds (PEREZ et al., 1992; GOMEZ; LEDBETTER, 1997).

The predominant chemotype in the oil analyzed was characterized by its terpene compounds, with distinction for the sesquiterpenes, many of which being of great interest to cosmetics and foods. Researches show that volatile oils with high levels of sesquiterpenes show antifungal and antibacterial activities (CHENG et al., 2004; CHENG; LIN; CHANG, 2005; CAKIR et al., 2005; VALERO; FRANCES, 2006). The presence of naphthalene derivatives is also described in other studies involving essential oil of ripe plums, and it can indicate possible fungistatic potential (ISMAIL; WILLIAMS; TUCKNOTT, 1981; GOMEZ; LEDBETTER; HARTSELL, 1993). In spite of their occurrence in all the regions where plum is produced, the thinning discards (Prunus salicina Lindl. Cv. Harry Pickstone) are fruits that are considered to have no economical value and correspond to about $90 \%$ of the unripe fruits.

\section{Conclusions}

The essential oil of thinning discards differs from the oil extracted from ripe fruits due to the prevalence of sesquiterpenes in the former, with possible antimicrobial potential - a fact that must be investigated in further studies. Besides its other properties, there are also possible applications for this essential oil in the chemical, pharmaceutical and nutrition industries, enabling the conversion of these solid residues from orchards into raw material for ingredients with high added value.

\section{Acknowledgements}

The authors are grateful to the Federal University of Santa Catarina, the Regional University of Blumenau, and to the Japanese community in Frei Rogerio, State of Santa Catarina, Brazil.

\section{References}

ADAMS, R. P. Identification of essential oil components by gas chromatography, mass spectroscopy. 4 th ed. Carol Stream: Allured Publishing Corporation, 2007.
AUGUSTÍ, M. et al. Estímulo del desarrollo de los frutos de hueso. Valência: Generalidad Valenciana/Consellería de Agricultura, Pesca y Alimentación, 1999.

CAKIR, A. et al. Antifungal properties of essential oil and crude extracts of Hypericum linarioides Bosse. Biochemical Systematics and Ecology, v. 33, n. 3, p. 245-256, 2005. http://dx.doi.org/10.1016/j. bse.2004.08.006

CHENG, S. S.; LIN, H. Y.; CHANG, S. T. Chemical composition and antifungal activity of essential oils from different tissues of Japanese cedar (Cryptomeria japonica). Journal of Agricultural and Food Chemistry, v. 53, n. 3, p. 614-619, 2005. http://dx.doi.org/10.1021/ jf0484529

CHENG, S. S. et al. Antitermitic and antifungal activities of essential oil of Calocedrus formosana Leaf and its composition. Journal Chemical Ecology, v. 30, n. 10, p. 1957-1967, 2004. http://dx.doi. org/10.1023/B:JOEC.0000045588.67710.74

DI BELLA, G. et al. Pesticide and plasticizer residues in bergamot essential Oliz from Calabria (Italy). Chemosphere, v. 56, n. 8, p. 777782, 2004. http://dx.doi.org/10.1016/j.chemosphere.2004.04.024

DOOL, V.; KRATZ, P. D. A generalization of the retention index system including linear temperature programmed gas-liquid partition chromatography. Journal Chromatography, v. 11, p. 463-471, 1963. http://dx.doi.org/10.1016/S0021-9673(01)80947-X

FAUST, M. Physiology of temperate zone fruit trees. New York: J. Wiley, 1989.

FLAMINI, G.; TEBANO, M.; CIONI, P. L. Composition of the essential oils from leafy parts of the shoots, flowers and fruits of Eryngium amethystinum from Amiata Mount (Tuscany, Italy). Food Chemistry, v. 107, n. 2, p. 671-674, 2008. http://dx.doi. org/10.1016/j.foodchem.2007.08.064

GOMEZ, E.; LEDBETTER, C. A. Development of volatile compounds during fruit maturation: characterization of apricot and plum $\mathrm{x}$ apricot hybrids. Journal Science Food Agriculture, v. 74, n. 4, p. 541-546, 1997. http://dx.doi.org/10.1002/(SICI)10970010(199708)74:4\%3C541::AID-JSFA851\%3E3.0.CO;2-D

GOMEZ, E.; LEDBETTER, C. A.; HARTSELL, P. L. Volatile compounds in apricot, plum, and their interspecific hybrids. Journal Agriculture Food Chemistry, v. 41, n. 10, p. 1669-1676, 1993. http://dx.doi.org/10.1021/jf00034a029

GONZÁLEZ-ROSSIA, D. et al. The inhibition of flowering by means of gibberellic acid application reduces the cost of hand thinning in Japanese plums (Prunus salicina Lindl.). Science Horticulture, v. 110, n. 4, p. 319-323, 2006.

GOTTLIEB, O. R.; MAGALHÃES, M. T. Modified distillation trap. Chemist Analyst, v. 49, p. 114, 1960.

HATANAKA, A. The biogeneration of green odour by green leaves. Phytochemistry, v. 34, n. 5, p. 1201-1218, 1993. http://dx.doi. org/10.1016/0031-9422(91)80003-J

HORVAT, R. J. et al. Comparison of the volatile compounds from several commercial plum cultivars. Journal Science of Food Agriculture, v. 60, n. 1, p. 21-23, 1992.

ISMAIL, H.; WILLIAMS, A.; TUCKNOTT, O. The flavors components of plums: an examination of the aroma components present in the headspace above four cultivars of intact plums, Marjorie's seedling, Merton Gem, NAIO and Victoria. Journal Science Food Agriculture, v. 32, n. 6 p. 498-502, 1981. http://dx.doi.org/10.1002/ jsfa.2740320513

JANTAN, I. et al. Insecticidal activities of the leaf oils of eight Cinnamomum species against Aedes aegypti and Aedes albopictus. 
Pharma Biology, v. 43, n. 6, p. 526-532, 2005. http://dx.doi. org/10.1080/13880200500220771

LOZANO, M. et al. Physicochemical and nutritional properties and volatile constituents of six Japanese plum (Prunus salicina Lindl.) cultivars. Euro Food Research Technology, v. 228, n. 3, p. 403-410, 2008. http://dx.doi.org/10.1007/s00217-008-0946-3

PEREZ, A. G. et al. Aroma components and free amino acids in strawberry variety Chandler during ripening. Journal Agriculture Food Chemistry, v. 40, n. 11, p. 2232-2235, 1992. http://dx.doi. org/10.1021/jf00023a036

REHMAN, S. et al. Essential oil composition of commercial black tea (Camellia sinensis). International Journal of Food Science and Technology, n. 43, p. 346-350, 2008. http://dx.doi.org/10.1111/ j.1365-2621.2006.01458.x

SILVERSTEIN, R. M.; WEBSTER, F. X.; KIEMLE, D. J. Identificação espectrométrica de compostos orgânicos. 7. ed. Tradução de Ricardo Bicca de Alencastro. Rio de Janeiro: LTC, 2007. p. 29.
SIMÕES, C. M. O.; SPITZER, V. Óleos voláteis. In: SIMÕES, C. M. O. et al. Farmacognosia: da planta ao medicamento. Porto Alegre: Editora da UFRGS; Florianópolis: Editora da UFSC, 2004. p. 467-495.

STEINBERG, E. Ameixa. São Paulo: Parma Ltda, 1990.

UTSUNOMIYA, H. et al. Components of essential oil from woods of Prunus mume Sieb. Et Zucc. Journal Oil Science, v. 54, n. 11, p. 609-612, 2005. http://dx.doi.org/10.5650/jos.54.609

VALERO, M.; FRANCES, E. Synergistic bactericidal effect of carvacrol, cinnalmaldehyde or thymol and refrigeration to inhibit Bacillus cereus in carrot broth. Food Microbiology, v. 23, n. 1, p. 68-73, 2006. http://dx.doi.org/10.1016/j.fm.2005.01.016

WANNES, W. A.; MHAMDI, B.; MARZOUK, B. Variations in essential oil and fatty acid composition during Myrtus communis var. italica fruit maturation. Food Chemistry, v. 112, n. 3, p. 621-626, 2009. http://dx.doi.org/10.1016/j.foodchem.2008.06.018 